\title{
Introduction to the Special Issue Art, Shamanism and Animism
}

\author{
Robert J. Wallis ${ }^{1, *}$ and Max Carocci ${ }^{2}$ \\ 1 Department of Art History, The Open University, Milton Keynes MK7 6AA, UK \\ 2 Department of Communications, Richmond the American International University in London, \\ Richmond TW10 6JP, UK; caroccm@richmond.ac.uk \\ * Correspondence: robert.wallis@open.ac.uk
}

Citation: Wallis, Robert J., and Max Carocci. 2021. Introduction to the Special Issue Art, Shamanism and Animism. Religions 12: 853. https:// doi.org/10.3390/rel12100853

Received: 27 September 2021

Accepted: 6 October 2021

Published: 11 October 2021

Publisher's Note: MDPI stays neutral with regard to jurisdictional claims in published maps and institutional affiliations.

Copyright: (C) 2021 by the authors. Licensee MDPI, Basel, Switzerland. This article is an open access article distributed under the terms and conditions of the Creative Commons Attribution (CC BY) license (https:// creativecommons.org/licenses/by/ $4.0 /)$.
Art, shamanism and animism are mutable, contested terms which, when brought together, present a highly charged package. Our aim here is not to rehearse the historical origins of these concepts, changing debates over their definition, nor to attempt to resolve (as if such a project is possible) what art, shamanism and animism actually are. Years of academic debate have not yet come to an agreement, and we want to underline the historical, political and epistemological contingency of these concepts. The merit of the discussions to date is that some scholars have stopped asking questions about what these phenomena are, to recognise their enduring if variously understood currency nonetheless, to adopt contextual analyses and to explore what art, shamanism and animism do in diverse and specific instances. As debates around these three terms continue to generate interest and strong opinions, we felt the urgency to explore them together in an unprecedented exercise which, to this date, has only been attempted with reference to selected disciplines, periods or regions (e.g., Fabietti 2014; King and McGranaghan 2020; Porr and Moro-Abadía 2021).

The respective turns to materiality (e.g., Conneller 2012; Fowler 2013), ontology (e.g., Holbraad and Pedersen 2017) and relational personhood (e.g., Watts 2013; Astor-Aguilera and Harvey 2020) over the last decades have impacted across the humanities and social sciences, permeating disciplinary boundaries and their territories. Scholars are now thinking about the cultural situatedness and relative values associated with objects and images-all things made or modified by humans for diverse social ends, which may be loosely termed 'art' (e.g., Ingold 2013; Harrison-Buck and Hendon 2018). New materialism recognises that materials are not inert, passive and only affective when humans do things with them to consider not only how artists and materials interact, but how the rhythm of intra-action between the various agents in processes of making, human and non-human, affect one another and are transformed anew (e.g., Jones and Cochrane 2018). 'New animism' challenges the hegemony of naturalism and recognises perspectival and other indigenous ontologies in which humans attempt to maintain good, respectful relations with diverse, agentive 'persons' in a wider-than-human social world. This has transformed Tylor's 'old' idea of a pre-religious and incorrect 'primitive' belief investing objects with souls, to collapse modern dichotomies between subjects/objects, minds/bodies, matter/spirit (e.g., Harvey 2005). Thought on shamanism has shifted away from issues of origins, geography, taxonomy and interior states of consciousness to recognising shamans as social mediators between human and other-than-human communities (e.g., Harvey and Wallis 2016). Shamans aim to adjust themselves to a unicultural (all persons are encultured) level in order to engage with a range of multinatural other-than-human bodies (all persons are embodied differently). Shamanistic practices are embodied and material, and 'art' and other 'things' are agentive, indeed collaborative, in shamans' active accomplishment of meaning.

We are, then, in this Special Issue of Religions, interested in critically examining current thinking in the range of fields which have engaged with art, shamanism and animism in the first decades of the twenty-first century. As scholars are coming to an understanding of art through an analysis of the specific contingencies in which human-made artefacts assume certain meanings through their manufacture, use, fruition and/or retirement, our contributors show a concern with 'when' and 'how' objects and representations may exceed 
conventional understandings of 'art' to fully articulate multiple scenarios in which artefacts, objects, and visual representations interface with academic discourses around animism and shamanism. Their approaches can broadly be situated within the ontological, relational and material turn across a range of disciplines over the last two decades, which, in varied ways, have challenged speciesist hierarchies and Cartesian bifurcations, looked beyond the weak notion of an ultimate, knowable objective reality, to recognise that ways of being and knowing are diversly contingent upon and emergent through relations between things. As Astor-Aguilera and Harvey (2020, p. 1) put it, 'to be human is to relate' and 'our relations are as much with things as with other humans'. This relational mutability interfaces with new materialism in the latter's challenge to linguistic, cultural and representational frames of thought which have neglected materials to recognise the vibrancy of matter and materiality of existence.

The elusive and heterogeneous class of objects and depictions gathered under the term 'art' challenge the language of formalism developed in art history to encompass different forms of material and visual expressions which evade a concern with aesthetics or style. The authors put in sharp focus the materiality of objects and representations while stressing their agentive, emotive, and performative aspects. This promotes a substantial distancing from a study of their appearances to an emphasis on what they do and 'who' they may be or become in their dealings with any number of interlocutors. What unites all the authors in this collection is the recognition that both things and images are deeply entangled with how different communities, human and other-than-human, experience life. This perspective shifts the attention from an obsolete concept of world-'view' to how reality is perceived through all the senses in all its aspects, both tangible and intangible. These papers redirect our theoretical concerns to how humans may apprehend the world they inhabit phenomenologically rather than simply seeing it and merely visualising it. Indeed, perhaps one of the issues' most provocative propositions is that in the minds of the many human actors examined here, there is no ontological difference between something seen, experienced in a dream, and something made, or material. The conventional distinction between visual and material culture here is collapsed in a series of 'manifestations' which reorient our thinking about how peoples around the world deal with the vast sensorium with which they are endowed.

If, as posited by these authors, the materiality of artefacts and images shapes the ways in which humans act, they consequentially have affects upon their phenomenal world. It follows that 'art' objects and images contribute to the construction of specific realities and, in turn, are constituted by humans through a mutual recognition of each other as active agents. This re-evaluation of the place held by artefacts in human society has encouraged further investigations into the multiple ways in which the disciplinary discourses of art history, anthropology and archaeology intersect, and perhaps most significantly, how they have historically skirted each other by maintaining mutually exclusive areas of remit and theoretical focus despite an equal interest in what humans make with intention and purpose.

As the authors here demonstrate with their studies, an examination of the space, role and nature of objects and images which, for analytical purposes, we call 'art' calls into question the very premises upon which its study has conventionally rested, that is, the study of representations. Indeed, the rich materials analysed by our authors in real-life situations appear to function as more than representations and, as it emerges from their conclusions, they ought to be understood through a language of presence, immanence and reality before they can be analysed through the idiom of form and a narrow focus on the visible qualities of images or artefacts.

Asking ontological questions about art is certainly not a new enterprise, as iconoclastic movements throughout history have highlighted many times. However, what this collection does is to reignite the debates around the status of images and tangible creative expressions through the lens of new theories drawn from new materialism, new animism and multi-species and relational thinking, which give credence to all the multifaceted ways 
in which humans think or experience 'things', images and image making. The strong emphasis on relationality derived from theories developed on studies of animism and shamanism has had the effect of decentring human agency to include objects and images in webs of social relations recognised by all of the groups represented here as being 'real' and, therefore, affecting phenomenal reality and behaviour.

The case studies included in this Special Issue present different approaches to the issues highlighted above. Almost half of them have been purposefully taken from current experiences in the ethnographic field from around the world (Matthews et al., Qu, Falck, Äikäs and Fonneland, Kendall) and/or with the purpose of highlighting continuities and ruptures with the past (Aldhouse-Green, VanPool and VanPool, Challis and Skinner, Fowler, Lau, Harrison-Buck and Freidel), to encourage future re-elaborations of the themes that they explore. As editors, we believe that this range of examples can bring further insights into the complexities generated by the multiple intersections of art, shamanism and animism.

In this editorial, we have chosen to introduce the eleven articles in relation to three broad themes: first, how a consideration of ontology, relationality and materiality may enable deeper analysis of certain objects/things as animate and agentive, and with which shamans negotiate specific social and historical contexts (Miranda Aldhouse-Green, Christine and Todd VanPool, Tiina Äikäs and Trude Fonneland); second, the ways in which current theoretical thinking presses analysis on the cosmo-ontological dimensions of certain shamanisms and/or animisms in new directions (Sam Challis and Andrew Skinner, George Lau, Feng Qu, Christine Falck); third, the possibilities and limitations of taxonomy and knowledge facilitated by such etic terminology as art, shamanism and animism (Chris Fowler, Eleanor Harrison-Buck and David A. Freidel, Maureen Matthews et al., Laurel Kendall). Permeating disciplinary boundaries, these themes offer one route by which to navigate the articles, even as they intersect across all of them.

\section{Deeper Analysis of Objects/Things}

Three of our contributors press for a deeper analysis of shamanic and/or animic objects/things in light of the ontological, relational and material turn, treating contexts from Europe to the Americas and from prehistory to the present. Miranda AldhouseGreen considers examples of human-animal, inter-species and cross-gender hybridity and liminality in European Iron Age and later art. La Tene 'art objects' and some of those from Rome's western provinces are well known for their stylised, abstract and sinuous decoration; Aldhouse-Green's approach negotiates the fluidity of design with fixity of material form in terms of shamans' liminal status. Shamans, for Aldhouse-Green, subvert norms in order to negotiate beings and different ways of being in different worlds. Playing with, for example, what is normal and what is subversion, what is nature and what is divine, in terms of shamanic 'oscillatory' behaviour enables a deeper analysis of the material at hand beyond the surface analysis of decoration.

Taking an operational view of 'art' in which objects made by humans may take personlike identities, Christine and Todd VanPool argue that iconographic coherence in creative expressions in Casas Grandes (Chihuahua, Mexico) is a precondition to personhood in human-made ritual and religious objects. Their analysis of Medio Period (AD 1200-1450) representations of other-than-human beings, such as the horned serpent and the doubleheaded macaw, reveals how consistency of images across media ensures the manifestation of personhood in objects. Things correctly decorated with images of incorporeal beings, the VanPools assert, are persons only insomuch as they faithfully reproduce intangible persons' distinctive features. In the world of Casas Grandes, they conclude, aesthetics ensure that reality's tangible and intangible registers remain connected through the mediation of objectpersons handled by shamans. In this way of understanding the relationships between different planes of cognition, ritual objects emerge as expressions of an ontology in which the fusion of the 'spiritual' and the 'material' turn 'real' everything that can be variably seen or experienced. 
In their examination of 'power animals' at the Isogaisa festival in Norway, Tiina Äikäs and Trude Fonneland explore how past Saami traditions meet present globalised 'shamanic' thinking and practice, as participants perform their indigeneity through visual, material and immaterial forms. Reindeer and bears, for instance, are embodied and made manifest through joik (song), dance, visualisation on drums and clothing and sacrifice at ritual sites. While there is no agreed-upon format for how shamanism should be done among these contemporary shamans, Äikäs and Fonneland's research shows how past, present and changing approaches to animist thinking and shamanist practice are entangled and creatively negotiated during this particular festival. While previous research on neo-shamans has focussed more on whether practices are authentic/derivative/neocolonial and on what practitioners think rather than what they do, Äikäs and Fonneland articulate how shamanic power animals are understood to disrupt conventional categories of subject/object, person/thing and matter/spirit, as performed in the relational intraaction between joik, dance, sacrifice and materiality.

\section{Cosmo-Ontological Dimensions}

The turn to ontology, relationality and materiality has significant implications for understanding how shamans and other humans engage with corporal and non-corporeal beings as well as animate object-things in the ongoing negotiation of cosmogonies and cosmologies-and the contestation of Eurocentric epistemological hegemony. Four articles take up this theme in case studies from Africa, Asia, Oceania and the Americas. In their paper, Sam Challis and Andrew Skinner re-consider the shamanistic approach to Southern African rock art in light of the ontological turn and new animism. The shamanistic approach has interpreted the imagery as 'part representation of', 'part reference to' shamanistic practices which facilitate human 'control' of such things as spirit-helpers, game, weather and disease. This is problematic for focussing myopically on human trance experience and ritual in an 'ontology of control' which subordinates non-human activity to human agency and delineates landscapes into Cartesian culture/nature, persons/resources and minds/bodies bifurcations. They look instead to the 'intersubjective character of the art' and 'the nature of the intercessions that shamans enact' according to historic and contemporary ethnographic accounts of a universe in which 'everything is transformative, contingent, momentary and responsive, and all in need of negotiation'. Social obligation in terms of mutually emergent 'compliance and influence' afford persons and things the same status and potential of 'aligning (or failing to align) socially in correspondence with their tendencies, and the ways in which others relate to and with them'. Challis and Skinner contribute to the ongoing theorising and re-framing of the established shamanistic approach to Southern African rock art by using ethnography to demonstrate the intraaction of all things involved in the making of rock art imagery, including the materials themselves, the intersubjectivity of human and other-than-human ontologies and how relationality and respectful comportment are at the core of shamanistic practice.

In his examination of the use of effigies among ancient Peruvians from the Ancash region, George Lau revisits ethnohistorical evidence and archaeological records to reveal how the language of kinship articulates descent relationships with lithified forebearers. The ongoing cycle of reciprocity, in which ancestors ensure prosperity and worshippers adhere to ritual obligations, firmly places stone persons in a cosmology of exchange which pivots around their 'vitalizing interventions' in the world of their progeny. Stone effigies, Lau maintains, were involved in social reproduction as agents which were simultaneously the producers and product of their descendants. Ancestors' simulacra were made to manifest their power in the phenomenal world for the benefit of the living while being energised by their offerings and libations. The genealogical continuity engendered by the production of ancestral effigies emerges as a cosmo-ontology characterised by agents' mutual recognition of different varieties of people inhabiting the same perceptual dimension across the generations. 
Returning to the traditional locus classicus of 'shamanism' in Asia, Feng Qu reconsiders shamanic ritual among Daur (as well as Evenki, Buriat and Bargu Mongols) in light of the ontological and material turn based on new fieldwork in north-eastern Inner Mongolia. Qu challenges a prevailing religious paradigm for shamanism, as well as modern dichotomies which go along with this view, by emphasising the sociality of the constituents, human and other-than-human, 'subjects' and 'objects', who all actively participate in making shamanic ceremonies. Qu proposes a relational model in which a 'social interface' permeates the cosmological boundaries between corporeal (humans, animals) and non-corporeal (ancestors, 'spirits') beings and material objects/things. Shamans are recognised as performing ceremonies which facilitate the participation of a variety of human and non-human agents in meaning-making which is grounded in materiality. Moreover, Daur shamanism enables communities (human and other-than-human, material and immaterial) to actively and creatively negotiate such current concerns as external political pressure, resource depletion and climate change.

In her article, Christiane Falck explores how during the month of Mother Mary (October), Nyaura women in the East Sepik catch a statue of Mother Mary in fishing nets, carry her around the village and are influenced and possessed by her spirit and spirits of God, reifying an origin myth when women caught ancestral clan spirits (wagen) in their nets and presided over ritual and social space. Falck extends Strathern's idea of dividuality, Gell's agency, Bird-David's relational personhood and Sahlins' concept of mytho-praxis (historical action as the projection of mythical relations) to highlight the importance of the 'cosmo-ontological dimensions' of historic trajectories of religious transformation (a shift from shamanism to Charismatic Christianity) and disruption of gender dominance (the co-option of men's ritual space by women) in Papua New Guinea.

\section{Taxonomical Limitations and Diverse Ontologies}

Four of the contributors engage critically with the limitations of the terms art, shamanism and animism to emphasise the diversity of ontologies in different contexts as well as the importance of historical change. Chris Fowler explores the possible value of Descola's four ontologies of animism, totemism, analogism and naturalism with regard to Neolithic Britain. He highlights their relative imprecision in this context and prefers a relational realist approach, recognising how material practices in events of making are relational, contingent and emergent and how the process of research itself reconfigures the assemblage of the archaeological materials encountered. This is not to say that art, shamanism and animism cannot be variously expressed and identified over the longue duree of the archaeological record, but Fowler makes the point that it is important to retain methodological and analytical rigour and to attend to ontological diversity and difference rather than to shoe-horn the evidence to fit pre-conceived notions of 'shamanism' or 'animism'.

The Mesoamerican material analysed by Eleanor Harrison-Buck and David A. Freidel dives into the heart of long-established discussions about the nature of animism and shamanism. In this sociocultural context, the impossibility to apply obsolete notions and definitions requires a reassessment of the categories of analysis which, the authors suggest, may benefit from relational approaches to experience, which, while partially resonating with other Amerindian societies, also chime with recent theoretical strands appearing under the rubrics of new materialism and new animism. The different states in which masks and mirrors operate in ancient Mesoamerica offer a backdrop for the authors' evaluations of animism and shamanism, here presented as contextual epistemological tools to know and exercise power in and over the world and its inhabitants. Through these examples, Harrison-Buck and Freidel offer a version of Mesoamerican ontology which challenges the conventional conflation of shamanism with small-scale societies and the correlation between priesthood and agricultural societies, providing an alternative model which can help us further future analyses beyond established paradigms.

Maureen Matthews, Roger Roulette and James Brook Wilson's in-depth examination of the role of pipes in Canada's new museology elicits important and timely questions 
about the nature of objects in museums and, in an era of decolonising their role, establishing new ways of relating to the world. At the confluence between spiritual and diplomatic objects, the pipe-protagonists of this ethnographic case study reveal how taxonomical incompatibilities have generated friction and misunderstandings across ethnic divides. First Nations peoples, in this case Anishinaabe and Cree, who believe and talk about these objects as animate and other-than-human persons, strongly defend their right to present pipes to the wider public as actants in their own right. Being simultaneously religious, political and educational agents, pipes open a channel between the visible and the invisible, obliging museum authorities to reassess their interpretative paradigms and educational objectives. This revolutionary and challenging perspective, while rebalancing power relations between settler colonial and indigenous peoples, also indicates a significant shift in perceptions and representations of religious objects in wider society.

In her article, Laurel Kendall uses animism (drawing on, e.g., Viveiros de Castro) as a heuristic to approach material things in Korean shamanic practice. This makes possible not only a re-focussing of attention on certain object-things which have been described as 'art' in the scholarship, but also recognition that they have not been analysed well. She finds that animation 'as an action verb' facilitates a 'deeper inquiry' into these objects. She identifies an 'adaptable ontology' in Korea in which 'mobile, mutable spirits' become associated with various object-things, be they quotidian, 'religious' or part of landscapes. These object-things, in turn, are identified as enabling shamans' ongoing adaptability in a 'transformed and highly commercialized South Korea'. Animism, or 'animation', then, allows Kendall to drill down into Korean shamanism in order to shed new light on its highly material engagements.

\section{Conclusions}

Our aim as editors of this Special Issue has been to enable the coming together of a range of approaches to the themes of art, shamanism and animism, exploring diverse contexts, both archaeological and anthropological, across a wide geographical range and chronological scope. The purposeful juxtaposition of different times and places, we hope, will encourage transversal readings of many potential interconnections between the different case studies presented here. We detected in the articles some commonalities and we grouped them according to these themes. Yet, we are aware that other alternative interpretations, perspectives and relations may emerge as each reader tacks between them, making their own course. The collection by no means attempts to be representative of the field, nor comprehensive, nor to resolve the veracity of art, shamanism and animism. Rather, the authors re-consider the heuristic potential of the intersection of these concepts while remaining critical of their limitations. This collection of new articles, then, does not seek closure on art, shamanism and animism; it re-frames approaches, presses analysis, raises further questions and, we hope, provokes debate.

Author Contributions: This introduction is co-authored by the editors. Both authors have read and agreed to the published version of the manuscript.

Funding: This research received no external funding.

Conflicts of Interest: The authors declare no conflict of interest.

\section{References}

Astor-Aguilera, Miguel, and Graham Harvey, eds. 2020. Rethinking Relations and Animism: Personhood and Materiality. London: Routledge.

Conneller, Chantal. 2012. An Archaeology of Materials: Substantial Transformations in Early Prehistoric Europe. London: Routledge.

Fabietti, Ugo. 2014. Materia Sacra. Milano: Cortina.

Fowler, Chris. 2013. The Emergent Past: A Relational realist Archaeology of Early Bronze Age Mortuary Practices. Oxford: Oxford University Press.

Harrison-Buck, Eleanor, and Julia A. Hendon, eds. 2018. Relational Identities and Other-Than-Human Agency in Archaeology. Louisville: University Press of Colorado.

Harvey, Graham. 2005. Animism: Respecting the Living World. London: Hurst and Co. 
Harvey, Graham, and Robert J. Wallis. 2016. Historical Dictionary of Shamanism, 2nd ed. Lanham: Rowman and Littlefield.

Holbraad, Martin, and Morten Axel Pedersen. 2017. The Ontological Turn: An Anthropological Exposition. Cambridge: Cambridge University Press.

Ingold, Tim. 2013. Making: Anthropology, Archaeology, Art and Architecture. London: Routledge.

Jones, Andrew M., and Andrew Cochrane. 2018. The Archaeology of Art. London: Routledge.

King, Rachel, and Mark McGranaghan. 2020. Birds, beasts and relatives: Animal subjectivities and frontier encounters. In The Pasts and Presence of Art in South Africa: Technologies, Ontologies, and Agents. Edited by Chris Wingfield, John Giblin and Rachel King. Cambridge: Cambridge University Press, pp. 91-110.

Porr, Martin, and Oscar Moro-Abadía, eds. 2021. Ontologies of Rock Art: Images, Relational Approaches and Indigenous Knowledges. London: Routledge.

Watts, Christopher. 2013. Relational Archaeologies: Humans, Animals, Things. London: Routledge. 